\section{Sonification as a Means of Enhancing the Detection of Gene Expression Levels from Formalin-Fixed, Paraffin-Embedded Biopsies}

BioTechniques 21:1074-1082 (December 1996) samples. This is accomplished by comparing the $\beta$-actin gene expression levels from flash-frozen and formalinfixed, paraffin-embedded tumor biopsy material of archival origin harvested from the same cancer patient.

Previously, various methods of isolating mRNA from flash-frozen tissues have been effectively used despite the requirement for prospective collection under clinical research protocols, which makes the mRNA difficult to ob- tain and of limited quantity $(5,6)$. Conversely, archival formalin-fixed, paraffin-embedded specimens are readily available in all hospital pathology departments. Archival material is well suited for research studies because it is frequently necessary to observe alterations in gene expression over a period of time. The accessibility of archival material means that independent replicate sections can be taken at various stages of disease progression to vali-

\begin{abstract}
We describe a novel approach for the isolation and quantification of mRNA from archival specimens by using oligo $(d T)_{25}$ paramagnetic beads and the reverse transcription polymerase chain reaction ( $R T$ $P C R$ ). A preliminary study is conducted to evaluate experimental conditions and the effects of varied periods of sonification on the yield of $m R N A$ isolated from formalinfixed, paraffin-embedded human biopsy samples. Validation of this approach will involve the comparison of observed $\beta$-actin gene expression levels among different samples from the same patient after various periods of sonification. The novelty of this method is that it offers a means of analyzing archival samples using semiquantitative RT-PCR following sonification-enhanced $m R N A$ extraction. The utility of this protocol allows for gene expression studies to be done effectively using the formalin-fixed, paraffin-embedded archival samples that are commonly available in all hospital pathology departments.
\end{abstract}

\section{INTRODUCTION}

The beta-actin ( $\beta$-actin) gene is frequently referred to as a so-called "housekeeping gene" due to its constant expression level. It thereby has frequently served effectively as an external reference gene in quantitative reverse transcription polymerase chain reaction (RT-PCR) studies $(1,5,6)$. The intention of this study is to offer a preliminary demonstration of how sonification can enhance the amount of messenger RNA (mRNA) recoverable from archival material. Presently, the RTPCR will be coupled with a novel method of mRNA extraction from formalin-fixed, paraffin-embedded

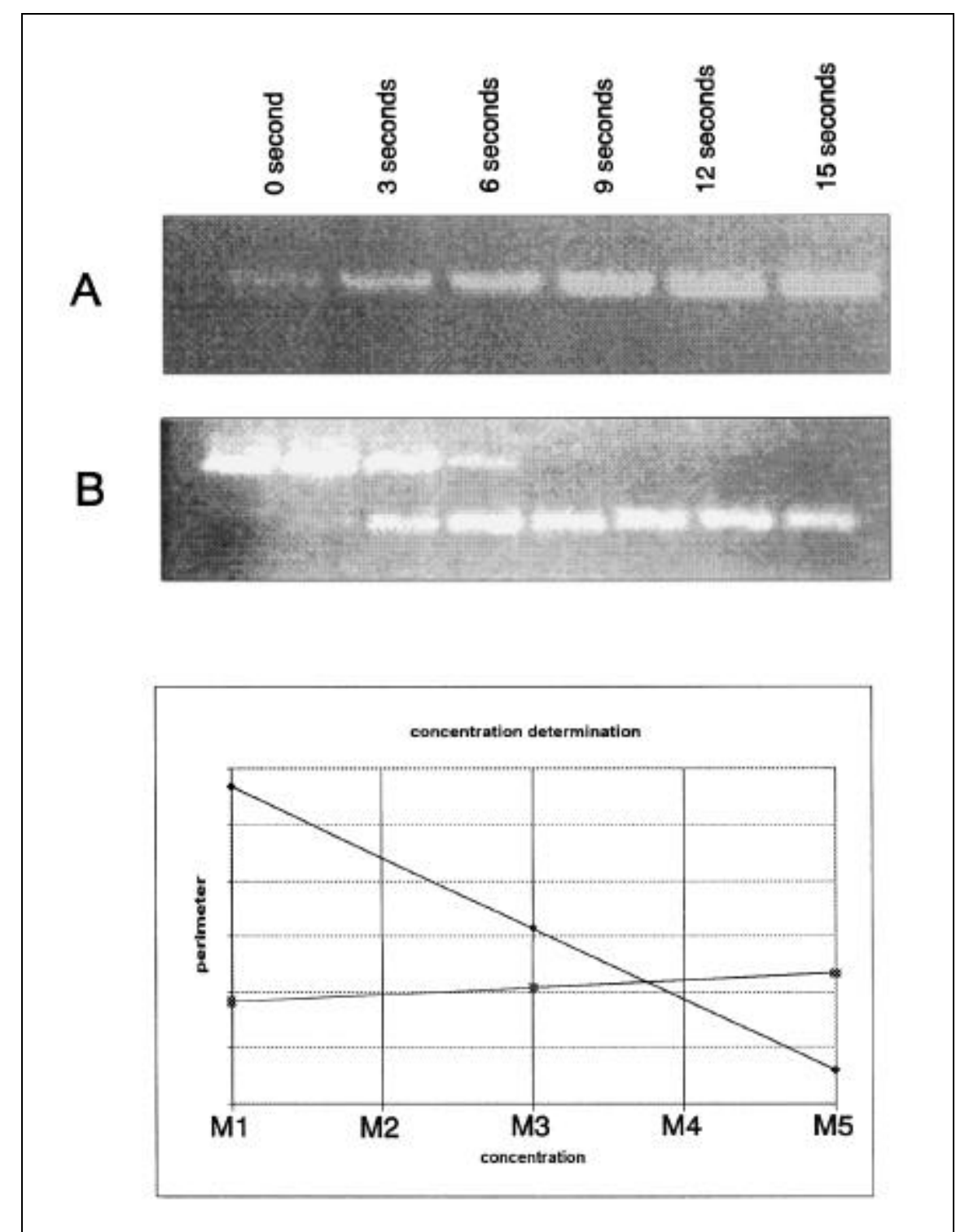

Figure 1. Effect of sonification on detection and quantification of $\beta$-actin cDNA by competitive RTPCR. (A) PCRs in which the duration of the sonification step is altered, as indicated above each column; otherwise, the reactions were identically prepared and analyzed. (B) Semiquantitative competitive RTPCR was performed using a factor of two. M1 through M5 represent the first five of the eight reactions; the graph is used to determine the exact concentration of sample cDNA to within a 5-fold difference. Linear regression analysis is used, and the results are plotted to determine the intersection of the slopes. This is the equimolar point for the standard fragment used in the competitive PCR relative to the target cDNA. 
date a result and yet leave ample tissue for further study.

Previously, paramagnetic beads were shown to be effective in extracting intact mRNA from formalin-fixed, paraffin-embedded human clinical biopsy material by Southern blot analysis (3). The use of RT-PCR provides a means by which the sensitivity of PCR in the detection of specific genes can provide many advantages over previous methods, especially in gene expression studies $(2,4,7-11)$. By modifying the method of mRNA extraction outlined by de Andrés et al. (3) by the addition of sonification, it has been shown that archival biopsy sections can be used as a source of intact mRNA for retrospective gene expression studies.

\section{MATERIALS AND METHODS}

\section{Tissue Procurement}

Fresh normal control and tumor specimens were obtained by surgical resection of biopsies from a patient undergoing surgery for colorectal cancer; a portion of each biopsy is flash-frozen in liquid nitrogen within $60 \mathrm{~s}$ of excision. The guidelines from our institution do not require informed consent in the case of such basic research studies. The remainder of the biopsy is used for routine pathological examination and prepared for archival storage by fixation in phosphate-buffered $10 \%$ formalin for $24 \mathrm{~h}$ followed by conventional processing and embedding in paraffin wax.

\section{Agarose Gel Electrophoresis}

Unless otherwise stated, $10 \mu \mathrm{L}$ of the amplified PCR products are mixed with $3 \mu \mathrm{L}$ of loading buffer $(30 \%$ [vol/vol] glycerol, $0.25 \%$ [vol/vol] bromophenol blue, $0.25 \%$ [vol/vol] xylene cyanol) and then separated by gel electrophoresis $\left(3 \%[\mathrm{wt} / \mathrm{vol}] \mathrm{NuSieve}^{\mathrm{TM}}\right.$ agarose; FMC BioProducts, Rockland, ME, USA), 1× TAE (40 mM Trisacetate, $1 \mathrm{mM}$ EDTA) and $5 \mu \mathrm{g} / \mathrm{mL}$ ethidium bromide. The gels are then viewed using 312-nm transillumination and photographed with Polaroid ${ }^{\circledR} 667$ film (Cambridge, MA, USA) using a red gelatin filter. 
Table 1. Primer Sequences Used in the Construction of RT-PCR Standards and in PCR Amplification

\begin{tabular}{|c|c|}
\hline Primer(s) & Sequence $5^{\prime} \rightarrow 3^{\prime}$ \\
\hline$(\beta$-actin-1a) & GCGGGAAATCGTGCGTGACATTCGCAAGTGAAATCTCCTCCG \\
\hline$(\beta$-actin-1b) & GATGGAGTTGAAGGTAGTTTCGTGATTTGATTCTGGACCATGGC \\
\hline$(\beta$-actin-2a) & GCGGGAAATCGTGCGTGACATT \\
\hline$(\beta$-actin-2b) & GATGGAGTTGAAGGTAGTTTCGTG \\
\hline \multicolumn{2}{|l|}{ a - sense } \\
\hline b - antisense & \\
\hline
\end{tabular}

Table 2. Effect of Sonification on $\beta$-Actin Gene Expression

\begin{tabular}{|ccc|}
\hline \multirow{2}{*}{ Durationa } & \multicolumn{2}{c|}{$\beta$-Actin Gene Expression $(\mathbf{X ~ 1 0 - 2 1} \mathbf{~ M})^{\mathbf{b}}$} \\
\cline { 2 - 3 } & Flash-Frozen & Paraffin-Embedded \\
\hline 0 seconds (3) & $10^{2} \pm 1.8$ & $<30 \pm 2.0$ \\
3 seconds (3) & $10^{2} \pm 1.8$ & $62 \pm 2.0$ \\
6 seconds (3) & $10^{2} \pm 1.8$ & $70 \pm 1.9$ \\
9 seconds (3) & $10^{2} \pm 1.8$ & $90 \pm 2.0$ \\
12 seconds (3) & $10^{2} \pm 1.8$ & $10^{2} \pm 1.8$ \\
15 seconds (3) & $10^{2} \pm 1.8$ & $10^{2} \pm 1.8$ \\
a(n) $=$ Number of samples; bgene expression = average \pm \% standard deviation \\
\hline
\end{tabular}

\section{Preparation of mRNA from Total RNA}

As a special precaution against ribonuclease (RNase) contamination, all material and apparatus coming in direct contact with any RNA-containing material or solution are pretreated according to the manufacturer's instructions (RNase Away ${ }^{\mathrm{TM}}$; Molecular Bio-Products, San Diego, CA, USA). For the flash-frozen biopsies, total RNA is isolated by the method of Chomczynski and Sacchi with modifications $(5,6)$. At the time of initial RNA extraction, a portion of the total RNA solution is precipitated in ethanol and pelleted. This pellet is stored at $-80^{\circ} \mathrm{C}$ for subsequent use in this study. Later, the pellet is redissolved in lysis/binding buffer (100 mM Tris-HCl, pH 8.0, $500 \mathrm{mM}$ LiCl, 10 mM EDTA, pH 8.0, 1\% LiDS, $5 \mathrm{mM}$ dithiothreitol [DTT]) to a volume of $100 \mu \mathrm{L}$. The mRNA in this solution is isolated using preconditioned paramagnetic oligo $(\mathrm{dT})_{25}$ Dynabeads ${ }^{\circledR}$ (mRNA DIRECT TM; Dynal, Oslo, Norway) according to the manufacturer's instructions. The mRNA is then eluted into $250 \mu \mathrm{L}$ of elution buffer $(2 \mathrm{mM}$ EDTA, pH 8.0). The sample is deoxyribonuclease I-digested (DNase I; Pharmacia Biotech, Uppsala, Sweden) to remove any remaining genomic DNA that might be present.

\section{Total Homogenization of Archival Biopsy}

Following microscopic examination and delimitation of an area-of-interest with a marker pen on the corresponding slide, each archival biopsy block to be analyzed $(250 \mathrm{mg})$ is sectioned using a sterile surgical blade. The deparaffinization of selected fragment involves the cutting away of any excess paraffin with a sterile RNase-free surgical blade. Next, the remaining paraffin is dissolved by stirring for $20 \mathrm{~min}$ in a 5 $\mathrm{mL}$ tube with $2 \mathrm{~mL}$ of xylene. The fragment is transferred to a $1.5-\mathrm{mL}$ tube and centrifuged for $10 \mathrm{~min}$ at $12000 \times \mathrm{g}$ and then transferred to a fresh $1.5-\mathrm{mL}$ tube, leaving behind any excess xylene. The pellet is then washed three times with $500 \mu \mathrm{L}$ of fresh RNase-free 


\section{Short Technical Reports}

absolute ethanol to remove any remaining xylene residue, which might later affect PCR amplification, and the pellet is allowed to air-dry. Pulverized glass $(100 \mathrm{mg}$ ) is prepared in a $190-\mathrm{mL}$ porcelain mortar using a $33-\mathrm{mm}$ pestle (Labassco, Gothenburg, Sweden) by mechanical grinding under a solution of RNase Away $(10 \mathrm{~mL})$ and allowed to stand for at least $24 \mathrm{~h}$. Later, the majority of the RNase Away solution is removed from the slurry by suction with a Pasteur pipet (Labora, Gothenburg, Sweden) and replaced with $5 \mathrm{~mL}$ of lysis/binding buffer just before tissue sample preparation. Next, the pellet of dried tissue is then cut into small fragments of about $50 \mathrm{mg}$ each; these fragments are placed in the same mortar as the powdered glass and completely pulverized by mechanical grinding for about $10 \mathrm{~min}$, forming a crude glasstissue emulsion. This emulsion is then transferred to a $10-\mathrm{mL}$ tube and soni- cated (Sonicor ${ }^{\mathrm{TM}}$ SC-100-22; Sonicor Instruments, Copiague, NY, USA) by immersing the lower portion of the sealed tube into the water-reservoir of the Sonicor. The sample is exposed five times to the $100 \%$ power setting for a duration of $3 \mathrm{~s}$, and following each sonification, an aliquot of the emulsion is transferred to a separate fresh $1.5-\mathrm{mL}$ tube for further examination.

\section{Extraction and RT of mRNA from Archival Biopsies}

A portion of each of the crude lysate solutions $(500 \mu \mathrm{L})$ from the previous step is equally divided among five fresh 1.5-mL tubes. Three of the five tubes are placed on ice, and the remaining tubes are left at room temperature. Prewashed oligo $(\mathrm{dT})_{25}$ paramagnetic beads (mRNA DIRECT) are added to the crude lysis solutions following the manufacturer's instructions. The mix- tures are allowed to anneal for $5 \mathrm{~min}$, and each tube is vortex mixed for $5 \mathrm{~s}$ and then placed in a magnetic field (MPC ${ }^{\mathrm{TM}}$; Dynal) for $5 \mathrm{~min}$, after which time the buffer containing most of the cellular debris is removed. Subsequently, the paramagnetic bead bound mRNA in each tube is washed twice with $1 \mathrm{~mL}$ of LiDS-washing buffer (10 mM Tris-HCl, $\mathrm{pH}$ 8.0, 0.15 M LiCl, 1 mM EDTA, $0.1 \%$ LiDS) and once with $1 \mathrm{~mL}$ of washing buffer $(10 \mathrm{mM}$ Tris$\mathrm{HCl}, \mathrm{pH} 8.0,0.15 \mathrm{M} \mathrm{LiCl}, 1 \mathrm{mM}$ EDTA) without LiDS at room temperature and resuspended in $250 \mu \mathrm{L}$ of LiDS-free washing buffer. The elution of the mRNA involves adding $5 \mu \mathrm{L}$ of elution buffer ( 2 mM EDTA, $\mathrm{pH}$ 8.0) to the solutions and heating the tubes to $65^{\circ} \mathrm{C}$ for $2 \mathrm{~min}$. Subsequently, each tube is placed in a magnetic field, and the supernatant containing the eluted mRNA is transferred to a $0.5-\mathrm{mL}$ tube containing buffer solution $(50 \mathrm{mM}$ Tris 
hydrochloride, $\mathrm{pH}$ 7.6, $10 \mathrm{mM} \mathrm{MnCl}_{2}$ ) and placed on ice. This same process is repeated with the remaining tubes with fresh paramagnetic beads. Finally, the solutions are DNase I-digested to remove any remaining genomic DNA that might be present. The DNase I is heatdeactivated, and an aliquot $(100 \mu \mathrm{L})$ of the mRNA solution from each tube is placed in a $0.5-\mathrm{mL}$ tube, where $\mathrm{RT}$ is carried out as previously described (5).

\section{Competitive RT-PCR Amplification}

The external standard is constructed from a well-defined genomic DNA template (PCR MIMICTM; CLONTECH Laboratories, Palo Alto, CA, USA). In Table 1, primer pair-1 is used to construct the DNA standard. The underlined modifications to the $3^{\prime}$ ends make each complimentary to different regions of the genomic DNA template. Primer pair-2 is used in all PCR amplifications and is based on previously determined sequences $(8,10)$. The competitive RT-PCR is accomplished by mixing fixed amounts of cDNA with varying amounts of competitor in the same tube. The PCR is performed with a 96-well microtiter format PHC-3 Thermal Cycler (Techne, Cambridge, England, UK). The PCR assay consists of: $5 \mu \mathrm{L} 10 \times$ buffer, $4 \mu \mathrm{L} \mathrm{MgCl} 2$ solution, $1 \mu \mathrm{L}$ 50× dNTP (Pharmacia Biotech), forward and reverse primers at 10 pmol in $2 \mu \mathrm{L}$ of distilled $\mathrm{H}_{2} \mathrm{O}$, respectively, $0.25 \mu \mathrm{L}$ (1.25 units) Taq DNA Polymerase (Perkin-Elmer, Norwalk, CT, USA), $5 \mu \mathrm{L}$ of cDNA solution and distilled $\mathrm{H}_{2} \mathrm{O}$ to make a total volume of $50 \mu \mathrm{L}$. Thirty cycles of PCR amplification are initiated with denaturation at $94^{\circ} \mathrm{C}$ for $3 \mathrm{~min}$ followed by a series of five cycles, each consisting of $94^{\circ} \mathrm{C}$ for $2 \mathrm{~min}$ (denaturation), $57^{\circ} \mathrm{C}$ for 2 min (annealing) and $72^{\circ} \mathrm{C}$ for $2 \mathrm{~min}$ (elongation). This is followed by a series of twenty-five cycles at $94^{\circ} \mathrm{C}$ for 1 $\min , 55^{\circ} \mathrm{C}$ for $1 \mathrm{~min}$ and $72^{\circ} \mathrm{C}$ for 1 $\mathrm{min}$. The last PCR cycle is a sample extension for $10 \mathrm{~min}$ at $72^{\circ} \mathrm{C}$ and a final soak cycle at $10^{\circ} \mathrm{C}$.

\section{Quantification of Gene Expression}

The quantification of gene expression is accomplished by agarose gel electrophoresis followed by quantita- tive digital image analysis (7). The two PCR products are equimolar in concentration when the bands of the standard and template amplicons have perimeter values of equal magnitude (Figure 1). This point is determined to be where the graphed lines intersect; the exact concentration at this point is determined by extrapolation from that point to the $\mathrm{x}$-axis.

\section{RESULTS AND DISCUSSION}

The application of sonification before mRNA enrichment using oligo(dT) ${ }_{25}$ paramagnetic beads was applied to samples from the same patient to compare the affects of the duration of sonification on the observed level of $\beta$ actin gene expression between flashfrozen and paraffin-embedded biopsies material. Since the $\beta$-actin gene expression had previously been used with great success in at least one other study, it was thought to be the obvious best choice for this study (5). It was subsequently shown that periods of sonification greater than 10 min greatly facilitate mRNA extraction from archival material yet had no apparent affect upon the yield of mRNA extracted from total RNA solution (data not shown). To accomplish this, we chose PCR primer sequences to measure $\beta$ actin gene expression that had previously proven reliable with a variety of tumors (12).

Preliminary trial runs were performed with fragments of deparaffinized biopsy tissue that had been completely pulverized by mechanical grinding for $10 \mathrm{~min}$ in a slurry of finely ground glass. The extraction of mRNA was performed without the use of sonification and revealed, following PCR amplification, that very little mRNA was present (Figure 1A). To minimize the affects of possible contamination of RNA solutions by genomic DNA, all RNA solutions were pretreated with DNase I before RT. Furthermore, the PCR primers used were designed in such a manner that the sense and antisense primers anneal to sequences separated by an exon. The presence of any contaminating genomic DNA would be revealed by the presence of an additional PCR product of a larger than expect- 
ed size. In this study, the presence of only a single PCR product after separation by gel electrophoresis demonstrated that no contaminating genomic DNA was present following the mRNA extraction procedure.

When dealing with archival material, the very low concentration of mRNA that is often observed can be attributed to the presence of autologous RNase activity, over-fixation with formalin during the preservation process and even excessive formalin cross-linking in the archival sample trapping intact mRNA within the interstitial spaces of the sample. These are only the most probable reasons for low mRNA yield when extracting mRNA from formalin-fixed biopsies and thereby logically account for the majority of the problems experienced with mRNA extraction. To circumvent these hindrances, the microscopic examination of the slide corresponding to the paraffin block to be analyzed should be done before sectioning the block. This allows for the quality of the material in different regions of the biopsy to be assessed before mRNA extraction and thus assist in reliable extraction by avoiding sections that contain the remnants of clotted blood, fat, connective and necrotic tissue. When these detrimental elements are removed from the population of cells to be analyzed, the remainder, when ground into an emulsion with pulverized glass and sonificated for at least $10 \mathrm{~min}$ before exposure to oligo $(\mathrm{dT})_{25}$ paramagnetic beads, dramatically enhances the amount of mRNA observed. It thereby seems that the use of paramagnetic beads followed by sonification provides a means of overcoming some of the difficulties that are associated with isolating mRNA from archival material and provides a dependable means of minimizing the detrimental affects of the aforementioned aspects of the formalin-fixation and embedding process.

\section{REFERENCES}

1.Bouaboula, M., P. Legoux, B. Pességué, B. Delpech, X. Dumont, M. Piechaczyk, P. Casellas and D. Shire. 1992. Standardization of mRNA titration using a PCR method involving co-amplification with a multispecific internal control. J. Biol. Chem. 267:21830-21838.
2.Chelly, J., J.C. Kaplan, P. Maire, S. Gautron and A. Kahn. 1988. Transcription of the dystrophin gene in human muscle and non-muscle tissue. Nature 333:858-860.

3.de Andrés, B., V. del Pozo, S. Gallardo, E. de Arruda-Chaves, B. Cárdaba, E. MartínOrozco, M. Posada, P. Palomino and C. Lahoz. 1995. Improved method for mRNA extraction from paraffin-embedded tissue. BioTechniques 18:42-44.

4.Delidow, B.C., J.J Peluso and B.A. White. 1989. Re-evaluation of the effects of growth hormone and prolactin on tadpole growth and development. Genet. Anal. Tech. Appl. 6:120124.

5.Horikoshi, T., K.D. Danenberg, T.H.W. Stadbauer, M. Volkenandt, L.C.C. Shea, K. Aigner, B. Gustavsson, L. Leichman et al. 1992. Quantitation of thymidylate synthase, dihydrofolate reductase, and DT-diaphorase gene expression in human tumors using the polymerase chain reaction. Cancer Res. 52:108-116.

6.Horikoshi, T., K. Danenberg, M. Volkenandt, T. Stadbauer and P.V. Danenberg. 1993. Quantitative measurement of relative gene expression in human tumors, p. 177-187. In B. White (Ed.), Current Methods and Applications. Humana Press, Ottawa.

7.Houze, T.A., L. Larsson, P.A. Larsson, G. Hansson, A. Asea and B. Gustavsson. 1996. Rapid detection of thymidylate synthase gene expression levels by semi-quantitative competitive reverse transcriptase polymerase chain reaction followed by quantitative digital image analysis. Tumor Biol. 17:306-319.

8.Montgomery, R.A. and M. Dallman. 1991. Analysis of cytokine gene expression during fetal thymic ontogeny using the polymerase chain reaction. J. Immunol. 147:554-560.

9.Murray, L.J., R. Lee and C. Martens. 1990. In vivo cytokine gene expression in T-cell subsets of the autoimmune MRL/Mp-Ipr mouse. Eur. J. Immunol. 20:163-170.

10.Rappolee, D.A., A. Wang, D. Mark and Z.J. Werb. 1989. Novel method for studying mRNA phenotypes in single and small numbers of cells. Cell Biochem. 39:71-81.

11.Saiki, R.K., S. Scharf, F. Falona, K.B. Mullis., G.T. Horn, H. Erlich and N. Arnheim. 1985. Enzymatic amplification of $\beta$ globin genomic sequences and resolution site analysis for diagnosis of sickle cell anemia. Science 230:1350-1353.

12.Watkins, D.I., S.N. McAdam, X. Liu, C.R. Strang, E.L. Milford, C.G. Levine and T.L. Garber. 1992. New recombinant HLA-B alleles in a tribe of South American Amerindians indicate rapid evolution of MHC class I loci. Nature 357:329-333.

This work was supported by a grant from the Swedish Cancer Society (0512B95-08XBC) and the Faculty of Medicine, University of Göteborg. Address correspondence to Thomas A. Houze, Östra University Hospital, University of Göteborg, Oncology Lab-2, 41685 Göteborg, Sweden. Internet:thomas.houze@mailbox.swipnet.se
Received 16 January 1996; accepted 8 July 1996.

\author{
Thomas A. Houze and Bengt \\ Gustavsson \\ Östra University Hospital \\ University of Göteborg \\ Göteborg, Sweden
}

